Article

\title{
Alignment Layer of Liquid Crystal Using Plant-Based Isoeugenol-Substituted Polystyrene
}

\author{
DaEun Yang ${ }^{\dagger}$, Kyutae Seo ${ }^{\dagger}$ and Hyo Kang *
}

BK-21 Four Graduate Program, Department of Chemical Engineering, Dong-A University, 37 Nakdong Daero 550beon-gil, Saha-gu, Busan 604-714, Korea; 1830133@donga.ac.kr (D.Y.); kyutae@donga.ac.kr (K.S.)

* Correspondence: hkang@dau.ac.kr; Tel.: +82-51-200-7720; Fax: +82-51-200-7728

+ These authors contributed equally to this work.

check for

updates

Citation: Yang, D.; Seo, K.; Kang, H. Alignment Layer of Liquid Crystal Using Plant-Based Isoeugenol-Substituted Polystyrene. Polymers 2021, 13, 547. https://doi.org/10.3390/polym13040547

Received: 20 January 2021

Accepted: 9 February 2021

Published: 12 February 2021

Publisher's Note: MDPI stays neutral with regard to jurisdictional claims in published maps and institutional affiliations.

Copyright: (C) 2021 by the authors. Licensee MDPI, Basel, Switzerland. This article is an open access article distributed under the terms and conditions of the Creative Commons Attribution (CC BY) license (https:/ / creativecommons.org/licenses/by/ $4.0 /)$.

\begin{abstract}
We synthesized a series of renewable and plant-based isoeugenol-substituted polystyrenes (PIEU\#, \# = 100, 80, 60, 40, and 20, where \# is the molar percent content of isoeugenol moiety), using polymer modification reactions to study their liquid crystal (LC) alignment behavior. In general, the LC cells fabricated using polymer film with a higher molar content of isoeugenol side groups showed vertical LC alignment behavior. This alignment behavior was well related to the surface energy value of the polymer layer. For example, vertical alignments were observed when the polar surface energy value of the polymer was smaller than approximately $3.59 \mathrm{~mJ} / \mathrm{m}^{2}$, generated by the nonpolar isoeugenol moiety with long and bulky carbon groups. Good alignment stability at $100{ }^{\circ} \mathrm{C}$ and under ultraviolet (UV) irradiation of $15 \mathrm{~J} / \mathrm{cm}^{2}$ was observed for the LC cells fabricated using PIEU100 as a LC alignment layer. Therefore, renewable isoeugenol-based materials can be used to produce an eco-friendly vertical LC alignment system.
\end{abstract}

Keywords: liquid crystal; alignment; vertical; polystyrene; isoeugenol

\section{Introduction}

Approximately 380 million tons of plastic are produced globally each year, and up to 13 million tons are released into water streams annually [1,2]. By 2050, 330 million tons of plastic are predicted to be released in rivers and oceans. Since only about 9 percent of plastic is recycled, much of the remainder pollutes the environment or sits in landfills [2-4]. Plastic can take up to 500 years to decompose while leaching toxic chemicals into the ground [5-7]. It is usually discarded after use and has a negative impact on the environment because of its extremely low biodegradability [8]. There is increasing scientific and societal concern about the effects of microplastics (MPs), commonly defined as plastic particles with a size below $5 \mathrm{~mm}$ [9-11]. The negative influence of MPs on the environment has been widely reported, and the toxicity of MPs in water has been demonstrated [12-15]. Bioplastics, which are bio-based, biodegradable, or both, have the same properties as conventional plastics and offer additional advantages [16-18]. These include reduced use of fossil fuel resources and lower carbon dioxide emissions $[19,20]$. Bioplastics are also less toxic and do not contain health-damaging additives, such as phthalates or bisphenol-A [21-23]. Bioplastics are considered a promising solution to concerns related to microplastics because they are environmentally friendly [24-27]. In this study, polymers containing bio-resources such as isoeugenol were prepared as a way to address pollution problems [28].

Isoeugenol belongs to the group of phenylpropenes, is found in essential oils of plants such as ylang-ylang (Cananga odorata), and is a component of wood smoke [29,30]. As one of the most important components of natural flavors, isoeugenol (2-methoxy-4-(prop-1-en1-yl)phenol) has been widely used in perfumes, soaps, detergents, air fresheners, and as a flavoring agent in cosmetics and food additives [31-35]. Because isoeugenol-constituted phenolic groups are known to have antioxidant and antibacterial functions, they can provide oxidation protection and bacterial fouling resistance [36-40]. For example, free radicals 
and active oxygen species have been associated with cardiovascular and inflammatory diseases, and even play a role in cancer and aging [41-43]. The antioxidant activity of isoeugenol can be attributed to its hydrogen atom and the electron-donating ability of ABTS (2,2'-azino-bis(3-ethylbenzothiazoline-6-sulfonic acid)) with radical-scavenging activity in isoeugenol [44-47]. The reducing power of isoeugenol has been noted to possess antioxidative potential because it breaks free radical chains and donates a hydrogen atom [48,49]. Moreover, isoeugenol can provide highly effective antimicrobial coatings that prevent bacterial attachment and apply bactericidal surfaces [50,51]. Isoeugenol can be used to add hydroxy groups to the surfaces of substrates, such as polymers and metals for a wide range of surface coating applications [52]. In addition, isoeugenol can be modified into polymers and used in the food industry and new pharmaceutical developments, and the antifungal activity of isoeugenol-binding materials can be manifested for pharmacological applications by docking isoeugenol to organic molecules [53-55].

Liquid crystal (LC) molecules have been extensively studied owing to their unique and attractive characteristics, such as solid-like ordering and liquid-like fluidity [56]. LC molecules have been known to exhibit anisotropic physico-chemical characteristics, such as optical and dielectric anisotropy, generated by external stimuli because of their interesting chemical structures [57]. Therefore, LC molecules have been used in various areas, such as information technology, energy and environmental technology, nanotechnology, and biotechnology, using their unique physico-chemical properties $[58,59]$. For example, LC molecules such as transmissive LCs, nematic LCs, reflective LCs, and cholesteric LCs have been widely used in the display industry [60]. Technologies to align LC molecules in the same direction on a substrate can be used in a variety of fields such as chemistry [61], physics [62], biology [63], and nanotechnology [64], by inducing interactions between LC molecules and surfaces on the substrate. Mechanical rubbing is a common method used to produce uniform orientation of LC molecules [65]. Polyimide (PI) derivatives are most commonly used as LC aligning materials using the rubbing technique because they provide stable LC-aligning properties [66]. Polyimide derivatives having alkyl and / or alkyloxy side groups, such as polyimide derivatives containing octadecyl and $n$-decyloxybiphenyloxy side chains, exhibit vertical LC aligning behaviors [67-69]. Although polyimide derivatives have been widely employed in the display industry, polyimide precursors are treated at high temperatures in order to produce polyimide film, and the film itself shows a yellowish color. Therefore, long-alkyl-chain-modified polystyrene (PS) derivatives have been synthesized as alternatives to polyimide derivatives to produce vertical LC orientation layers. The benefits of using PS instead of PI derivatives include high optical transparency, and more convenient processing and fabrication. In addition, PS derivatives with enhanced thermal properties can be obtained through copolymerization with methyl methacrylate [70], acrylonitrile [71], divinylbenzene [72], and trivinylbenzene [73], etc., or by incorporating specific moieties or functional groups into the side chain of polystyrene. For example, the introduction of coumarin as a dye [74], oryzanol as a plant extraction resource [75], and the imide moieties [76] into the side chain of polystyrene improves the $T_{\mathrm{g}}$ value. PS derivatives have been enhanced via a simple polymer reaction to produce vertical LC orientation layers for next-generation applications owing to their advantages, such as low-temperature processability and good solubility in many organic solvents [77]. The molecular orientation of polymers, such as isomeric groups on polymeric surfaces, is an important factor in inducing LC aligning behavior because of the interactions and/or steric repulsions between the polymer surface and the LC molecule [78,79]. In recent studies, much research has been conducted on liquid crystal alignment methods in order to overcome the limitations of mechanical rubbing using polyimide. For example, among the non-contact methods, photoalignment and photopatterning technology, which are promising alignment methods, have been noted as alternatives to rubbing technology. Another example is self-alignment technology or PI layer-less orientation technology, which introduces dopants such as nanoparticles and surfactants into the LC medium for next-generation applications. 
In this study, bio-based isoeugenol-substituted polystyrenes (PIEU\#) were synthesized to obtain vertical alignment of LCs and to study the effect of the molar content of the isoeugenyl side groups on LC alignment behavior. We selected isoeugenol, with its phenylpropene structure, as a modifier into the side chain of the polystyrene in order to investigate LC alignment behavior. Plant-based isoeugenol is not only effective and inexpensive for fabrication, but also safe and environmentally friendly. The optical and electrical properties of LC cells fabricated using renewable polymer films were also investigated.

\section{Materials and Methods}

\subsection{Materials}

4-Chloromethylstyrene, isoeugenol, and potassium carbonate were purchased from Aldrich Chemical Co., and a nematic LC, MLC-6608 $\left(n_{\mathrm{e}}=1.5586, n_{\mathrm{O}}=1.4756\right.$, and $\Delta \varepsilon=-4.2$, where $n_{\mathrm{e}}, n_{\mathrm{o}}$, and $\Delta \varepsilon$ represent the extraordinary refractive index, ordinary refractive index, and dielectric anisotropy, respectively) was purchased from Merck Co (Pyeongtaek, Korea). $N, N^{\prime}$-Dimethylacetamide (DMAc) and ethanol were dried over molecular sieves (4 A). Tetrahydrofuran (THF) was dried by refluxing with benzophenone and sodium, followed by distillation. 4-Chloromethylstyrene was purified by column chromatography on silica gel using hexane as an eluent to remove any impurities and inhibitors (tert-butylcatechol and nitroparaffin). Poly(4-chloromethylstyrene) (PCMS) was synthesized through conventional free radical polymerization of 4-chloromethylstyrene using 2,2'-azoisobutyronitrile (AIBN) under a nitrogen atmosphere. AIBN (Junsei Chemical Co., Ltd., Tokyo, Japan) was used as the initiator. AIBN was purified by crystallization using methanol. All other reagents and solvents were used as received.

\subsection{Preparation of Isoeugenol-Modified Polystyrene}

The following procedure was used to synthesize all of the isoeugenol-substituted polystyrenes, PIEU\#, where \# represents the molar content (in \%) of isoeugenol moiety in the side group. The synthesis of isoeugenol-substituted polystyrene (PIEU100) is provided as an example. A mixture of isoeugenol $(0.49 \mathrm{~g}, 2.95 \mathrm{mmol}, 150 \mathrm{~mol} \%$ compared with PCMS) and potassium carbonate $(0.50 \mathrm{~g}, 3.54 \mathrm{mmol})$ in $N, N^{\prime}$-dimethylacetamide (DMAc, $30 \mathrm{~mL}$ ) was heated to $75^{\circ} \mathrm{C}$. A PCMS solution $(0.3 \mathrm{~g}, 1.97 \mathrm{mmol})$ in DMAc $(20 \mathrm{~mL})$ was added to the mixture, which was then magnetically stirred at $70^{\circ} \mathrm{C}$ for $24 \mathrm{~h}$ under a nitrogen atmosphere. The mixture was cooled to room temperature and poured into methanol to obtain a white precipitate. The precipitate was further purified by several reprecipitations from the DMAc solution into methanol and then washed with hot methanol to remove potassium carbonate and any remaining salts. PIEU100 was obtained in yields above $80 \%$ after drying overnight in a vacuum. The degree of substitution of the chloromethyl group with the isoeugenyl methyl ether group was found to be almost $100 \%$ within experimental error.

PIEU100 ${ }^{1} \mathrm{H}$ NMR $\left(\mathrm{CDCl}_{3}\right): \delta=0.91-1.42\left(\mathrm{~m}, 3 \mathrm{H},-\mathrm{CH}_{2}-\mathrm{CH}-\mathrm{Ph}-\right), 1.61-1.83(\mathrm{~d}, 3 \mathrm{H}$, $\left.-\mathrm{CH}=\mathrm{CH}-\mathrm{CH}_{3}\right), 3.51-3.92\left(\mathrm{~s}, 3 \mathrm{H},-\mathrm{CH}_{2}-\mathrm{O}-\mathrm{Ph}\left(\mathrm{OCH}_{3}\right)-\mathrm{CH}=\right), 4.61-5.11\left(\mathrm{~s}, 2 \mathrm{H},-\mathrm{Ph}-\mathrm{CH}_{2}-\right.$ $\mathrm{O}-)$, 5.94-6.13 (m, 1H, $\left.-\mathrm{CH}=\mathrm{CH}-\mathrm{CH}_{3}\right), 6.12-6.31(\mathrm{~d}, 1 \mathrm{H},-\mathrm{Ph}-\mathrm{CH}=\mathrm{CH}-), 6.31-7.23(\mathrm{~m}, 7 \mathrm{H}$, $\left.-\mathrm{CH}_{2}-\mathrm{CH}-\mathrm{PhH}-\mathrm{CH}_{2}-\mathrm{O}-\mathrm{PhH}\left(\mathrm{OCH}_{3}\right)-\mathrm{CH}_{2}=\right)$.

Other polystyrene derivatives containing isoeugenol side groups were synthesized using the same procedure used for the preparation of PIEU100, except for differing amounts of isoeugenol in the reaction. For example, PIEU80, PIEU60, PIEU40, and PIEU20 were prepared with $0.27 \mathrm{~g}(1.92 \mathrm{mmol}), 0.19 \mathrm{~g}(1.15 \mathrm{mmol}), 0.14 \mathrm{~g}(0.77 \mathrm{mmol})$, and $0.06 \mathrm{~g}$ $(0.39 \mathrm{mmol})$ of isoeugenol, respectively, using slight excess amounts of potassium carbonate (0.50 g, $3.54 \mathrm{mmol}, 180 \mathrm{~mol} \%$ compared with PCMS).

PIEU $80{ }^{1} \mathrm{H}$ NMR $\left(\mathrm{CDCl}_{3}\right): \delta=0.93-1.44\left(\mathrm{~m}, 3 \mathrm{H},-\mathrm{CH}_{2}-\mathrm{CH}-\mathrm{Ph}-\right), 1.62-1.82(\mathrm{~d}, 3 \mathrm{H}$, $\left.-\mathrm{CH}=\mathrm{CH}-\mathrm{CH}_{3}\right), 3.41-3.82\left(\mathrm{~s}, 3 \mathrm{H},-\mathrm{CH}_{2}-\mathrm{O}-\mathrm{Ph}\left(\mathrm{OCH}_{3}\right)-\mathrm{CH}=\right), 4.38-4.61\left(\mathrm{~s}, 2 \mathrm{H},-\mathrm{Ph}-\mathrm{CH}_{2}-\mathrm{Cl}\right)$, 4.61-5.13 (s, 2H, -Ph-CH $-\mathrm{O}-)$, 5.91-6.12 (m, 1H, - $\left.\mathrm{CH}=\mathrm{CH}-\mathrm{CH}_{3}\right), 6.09-6.31$ (d, 1H, -Ph$\mathrm{CH}=\mathrm{CH}-), 6.32-7.24\left(\mathrm{~m}, 4 \mathrm{H},-\mathrm{CH}_{2}-\mathrm{CH}-\mathrm{PhH}-\mathrm{CH}_{2}-\mathrm{Cl}\right), 6.32-7.24\left(\mathrm{~m}, 7 \mathrm{H},-\mathrm{CH}_{2}-\mathrm{CH}-\mathrm{PhH}-\right.$ $\left.\mathrm{CH}_{2}-\mathrm{O}-\mathrm{PhH}\left(\mathrm{OCH}_{3}\right)-\mathrm{CH}_{2}=\right)$. 
PIEU $60{ }^{1} \mathrm{H}$ NMR $\left(\mathrm{CDCl}_{3}\right): \delta=0.93-1.43\left(\mathrm{~m}, 3 \mathrm{H},-\mathrm{CH}_{2}-\mathrm{CH}-\mathrm{Ph}-\right), 1.61-1.83(\mathrm{~d}, 3 \mathrm{H}$, $\left.-\mathrm{CH}=\mathrm{CH}-\mathrm{CH}_{3}\right), 3.41-3.83\left(\mathrm{~s}, 3 \mathrm{H},-\mathrm{CH}_{2}-\mathrm{O}-\mathrm{Ph}\left(\mathrm{OCH}_{3}\right)-\mathrm{CH}=\right), 4.38-4.61\left(\mathrm{~s}, 2 \mathrm{H},-\mathrm{Ph}-\mathrm{CH}_{2}-\right.$ $\mathrm{Cl}), 4.61-5.14\left(\mathrm{~s}, 2 \mathrm{H},-\mathrm{Ph}-\mathrm{CH}_{2}-\mathrm{O}-\right), 5.92-6.13\left(\mathrm{~m}, 1 \mathrm{H},-\mathrm{CH}=\mathrm{CH}-\mathrm{CH}_{3}\right), 6.08-6.32(\mathrm{~m}, 1 \mathrm{H}$, $-\mathrm{Ph}-\mathrm{CH}=\mathrm{CH}-), 6.31-7.25\left(\mathrm{~m}, 4 \mathrm{H},-\mathrm{CH}_{2}-\mathrm{CH}-\mathrm{PhH}-\mathrm{CH}_{2}-\mathrm{Cl}\right), 6.31-7.25\left(\mathrm{~m}, 7 \mathrm{H}, \mathrm{CH}_{2}-\mathrm{CH}-\right.$ $\left.\mathrm{PhH}-\mathrm{CH}_{2}-\mathrm{O}-\mathrm{PhH}\left(\mathrm{OCH}_{3}\right)-\mathrm{CH}_{2}=\right)$.

PIEU $40{ }^{1} \mathrm{H}$ NMR $\left(\mathrm{CDCl}_{3}\right): \delta=0.93-1.43\left(\mathrm{~m}, 3 \mathrm{H},-\mathrm{CH}_{2}-\mathrm{CH}-\mathrm{Ph}-\right), 1.62-1.82(\mathrm{~d}, 3 \mathrm{H}$, $\left.-\mathrm{CH}=\mathrm{CH}-\mathrm{CH}_{3}\right), 3.41-3.83\left(\mathrm{~s}, 3 \mathrm{H},-\mathrm{CH}_{2}-\mathrm{O}-\mathrm{Ph}\left(\mathrm{OCH}_{3}\right)-\mathrm{CH}=\right), 4.38-4.62\left(\mathrm{~s}, 2 \mathrm{H},-\mathrm{Ph}-\mathrm{CH}_{2}-\right.$ $\mathrm{Cl}), 4.62-5.11\left(\mathrm{~s}, 2 \mathrm{H},-\mathrm{Ph}-\mathrm{CH}_{2}-\mathrm{O}-\right), 5.93-6.14\left(\mathrm{~m}, 1 \mathrm{H},-\mathrm{CH}=\mathrm{CH}-\mathrm{CH}_{3}\right), 6.09-6.33(\mathrm{~m}, 1 \mathrm{H}$, $-\mathrm{Ph}-\mathrm{CH}=\mathrm{CH}-), 6.34-7.25\left(\mathrm{~m}, 4 \mathrm{H},-\mathrm{CH}_{2}-\mathrm{CH}-\mathrm{PhH}-\mathrm{CH}_{2}-\mathrm{Cl}\right), 6.34-7.25\left(\mathrm{~m}, 7 \mathrm{H},-\mathrm{CH}_{2}-\mathrm{CH}-\right.$ $\left.\mathrm{PhH}-\mathrm{CH}_{2}-\mathrm{O}-\mathrm{PhH}\left(\mathrm{OCH}_{3}\right)-\mathrm{CH}_{2}=\right)$.

PIEU $20{ }^{1} \mathrm{H}$ NMR $\left(\mathrm{CDCl}_{3}\right): \delta=0.95-1.45\left(\mathrm{~m}, 3 \mathrm{H},-\mathrm{CH}_{2}-\mathrm{CH}-\mathrm{Ph}-\right), 1.63-1.82(\mathrm{~d}, 3 \mathrm{H}$, $\left.-\mathrm{CH}=\mathrm{CH}-\mathrm{CH}_{3}\right), 3.42-3.83\left(\mathrm{~s}, 3 \mathrm{H},-\mathrm{CH}_{2}-\mathrm{O}-\mathrm{Ph}\left(\mathrm{OCH}_{3}\right)-\mathrm{CH}=\right), 4.38-4.62\left(\mathrm{~s}, 2 \mathrm{H},-\mathrm{Ph}-\mathrm{CH}_{2}-\right.$ $\mathrm{Cl}), 4.62-5.14\left(\mathrm{~s}, 2 \mathrm{H},-\mathrm{Ph}-\mathrm{CH}_{2}-\mathrm{O}-\right), 5.93-6.11\left(\mathrm{~m}, 1 \mathrm{H},-\mathrm{CH}=\mathrm{CH}-\mathrm{CH}_{3}\right), 6.07-6.36(\mathrm{~m}, 1 \mathrm{H}$, $-\mathrm{Ph}-\mathrm{CH}=\mathrm{CH}-), 6.34-7.24\left(\mathrm{~m}, 4 \mathrm{H},-\mathrm{CH}_{2}-\mathrm{CH}-\mathrm{PhH}-\mathrm{CH}_{2}-\mathrm{Cl}\right), 6.34-7.24\left(\mathrm{~m}, 7 \mathrm{H},-\mathrm{CH}_{2}-\mathrm{CH}-\right.$ $\left.\mathrm{PhH}-\mathrm{CH}_{2}-\mathrm{O}-\mathrm{PhH}\left(\mathrm{OCH}_{3}\right)-\mathrm{CH}_{2}=\right)$.

\subsection{Film Preparation and LC Cell Assembly}

Solutions of PIEU\# in THF (1 wt.\%) were prepared. These solutions were filtered using a poly(tetrafluoroethylene) (PTFE) membrane with a pore size of $0.45 \mu \mathrm{m}$. Thin films of the polymers were prepared by spin-coating (2000 rpm, $90 \mathrm{~s}$ ) onto glass substrates. The LC cells were fabricated using a polymer film on glass slides. The LC cells were constructed by assembling films together using spacers with a thickness of $4.25 \mu \mathrm{m}$. The cells were filled with a nematic LC, MLC-6608. The manufactured LC cells were sealed using epoxy glue.

\subsection{Instrumentation}

Proton nuclear magnetic resonance $\left({ }^{1} \mathrm{H}\right.$ NMR) measurements were carried out on a Bruker AVANCE spectrometer at $300 \mathrm{MHz}$. Differential scanning calorimetry (DSC) measurements were carried out on a TA Instruments Q-10 at heating and cooling rates of $10{ }^{\circ} \mathrm{C} \cdot \mathrm{min}^{-1}$ under a nitrogen atmosphere. The contact angles of distilled water, methylene iodide, formamide, and ethylene glycol on the polymer films were determined with a Kruss DSA10 contact angle analyzer equipped with drop shape analysis software. Surface energy values were calculated using the Owens-Wendt equation:

$$
\gamma_{s l}=\gamma_{s}+\gamma_{l}-2\left(\gamma_{s}{ }^{d} \gamma_{l}{ }^{d}\right)^{1 / 2}-2\left(\gamma_{s}{ }^{p} \gamma_{l}{ }^{p}\right)^{1 / 2}
$$

where $\gamma_{l}$ is the surface energy of the liquid, $\gamma_{s l}$ is the interfacial energy of the solid/liquid interface, and $\gamma_{s}$ is the surface energy of the solid. $\gamma_{s}{ }^{d}$ and $\gamma_{s}{ }^{p}$ are the dispersive and polar components of the surface energy of the solid, respectively. $\gamma_{l}{ }^{d}$ and $\gamma_{l}{ }^{p}$ are the dispersive and polar components of the surface tension of the liquid, respectively. $\gamma_{l}^{d}$ and $\gamma_{l}{ }^{p}$ are known for the test liquids, and $\gamma_{s}{ }^{d}$ and $\gamma_{s}{ }^{p}$ can be calculated from the measured static contact angles [80]. Polarized optical microscopy (POM) images of the LC cell were taken using an optical microscope (Nikon, ECLIPSE E600 POL, Tokyo, Japan) equipped with a polarizer and digital camera (Nikon, COOLPIX995, Tokyo, Japan).

\section{Results}

\subsection{Synthesis and Characterization of Isoeugenol-Modified Polystyrene}

Figure 1 shows the synthetic routes to the isoeugenol-substituted polystyrenes (PIEU100) and copolymers (PIEU80, PIEU60, PIEU40, and PIEU20, where \# is the molar content (\%) of isoeugenol side groups). Copolymers with different degrees of substitution were obtained by varying the amount of isoeugenol in the reaction as shown in Table 1. Almost 100\% conversion of chloromethyl to isoeugenyl methyl ether was obtained when $150 \mathrm{~mol} \%$ of isoeugenol was used at $70^{\circ} \mathrm{C}$ for $24 \mathrm{~h}$, as shown by assignment of the respective proton peaks of the isoeugenol-containing homopolymer (PIEU100) (Figure 2). Figure 2 shows the proton nuclear magnetic resonance $\left({ }^{1} \mathrm{H}\right.$ NMR) spectrum and assignment of the respective 
peaks of PIEU100, confirming the chemical composition of the monomeric units in the obtained polymers. The spectrum indicates the presence of protons from the phenyl ring of the styrene backbone $(\delta=6.3-7.2 \mathrm{ppm}$ (peak a)). The proton peaks from the isoeugenol side chains ( $\delta=6.1-6.3$ (peak b), 5.9-6.1 (peak c), 3.5-3.9 (peak e), and 1.6-1.8 (peak f) indicate the inclusion of isoeugenol moieties in the polymer. The content of isoeugenol can be calculated by comparing the integrated area of the proton peaks of the isoeugenol side chain $(\delta=3.5-3.9 \mathrm{ppm}$, peak e) and chloromethyl side chains $(\delta=4.6-5.1 \mathrm{ppm}$, peak d). Similar integrations and calculations for PIEU80, PIEU60, PIEU40, and PIEU20 were performed and were typically within $\pm 10 \%$ of the expected values from the synthesis. These polymers have good solubility in medium-polarity solvents with low boiling temperatures, such as chloroform and tetrahydrofuran, as well as in aprotic polar solvents, such as $N, N^{\prime}$-dimethylacetamide (DMAc), $N, N^{\prime}$-dimethylformamide (DMF), and $N$-methyl-2pyrrolidone (NMP). The good solubility of all polymers in common solvents is of use in fabrication for film applications.

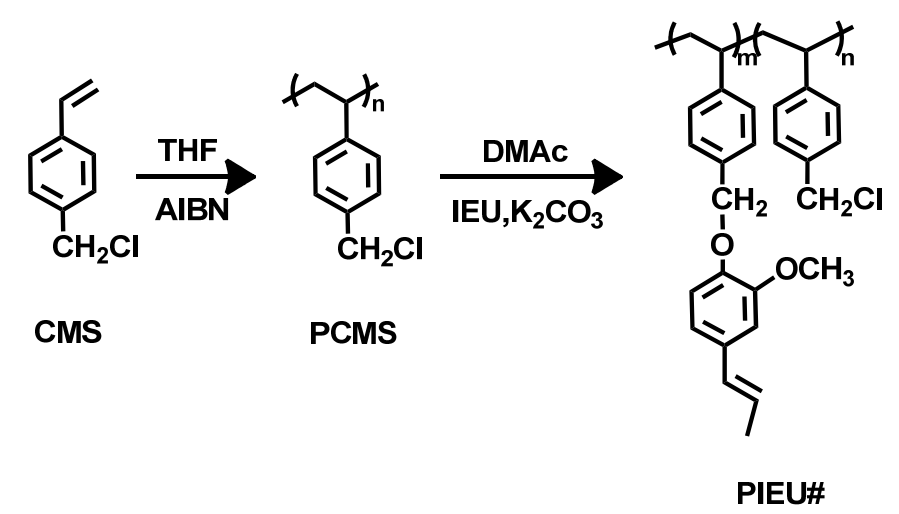

Figure 1. Synthetic route to isoeugenol modified polystyrene (PIEU\#), where \# indicates the mole percent of isoeugenol containing monomeric units in the polymer.

Table 1. Reaction conditions and results for the synthesis of isoeugenol modified polystyrene (PIEU\#).

\begin{tabular}{cccc}
\hline $\begin{array}{c}\text { Polymer } \\
\text { Designation }\end{array}$ & $\begin{array}{c}\text { Feed Ratio of } \\
\text { Isoeugenol [mol\%] }\end{array}$ & $\begin{array}{c}\text { Degree of } \\
\text { Substitution [\%] }\end{array}$ & $\boldsymbol{T}_{\mathbf{g}}\left[{ }^{\circ} \mathbf{C}\right]$ \\
\hline PIEU20 & 20 & 20 & 96 \\
PIEU40 & 40 & 40 & 76 \\
PIEU60 & 60 & 60 & 77 \\
PIEU80 & 80 & 80 & 77 \\
PIEU100 & 150 & 100 & 74 \\
\hline
\end{tabular}

The thermal characteristics of the synthesized polymers were investigated using differential scanning calorimetry. All the samples were amorphous materials, as only one glassy-to-rubbery transition behavior was observed in the differential scanning calorimetry thermogram (Figure 3). As the molar content of the isoeugenol side group increased from $20 \%$ to $100 \%$, the $T_{\mathrm{g}}$ value decreased from $96{ }^{\circ} \mathrm{C}$ for PIEU20 to $74{ }^{\circ} \mathrm{C}$ for PIEU100. The decrease in the $T_{\mathrm{g}}$ value of the polystyrene derivatives with increasing molar content of the bulky side group has been previously reported and was ascribed to an increase in the free volume that is the space present inside the polymer, as polymers with larger free volumes have lower $T_{\mathrm{g}}$ values $[81,82]$. Additionally, the $T_{\mathrm{g}}$ value of the PS derivatives depends on the interplay of the free volume inside the polymer and physico-chemical interactions among the polymer chains [83]. Therefore, the trend of the $T_{\mathrm{g}}$ value is interpreted with the other two analysis points: free volume effect and interaction effect. For example, in this study, from PIEU20 to PIEU40, the $T_{\mathrm{g}}$ value decreased dramatically because the free volume effect was dominant. When the molar content of the isoeugenol containing monomer units in PIEU\# was greater than about $40 \mathrm{~mol} \%$ (PIEU40, PIEU60, PIEU80, and PIEU100), the 
difference in $T_{\mathrm{g}}$ values was subtle because the interaction among the isoeugenol side chains was also expressed.
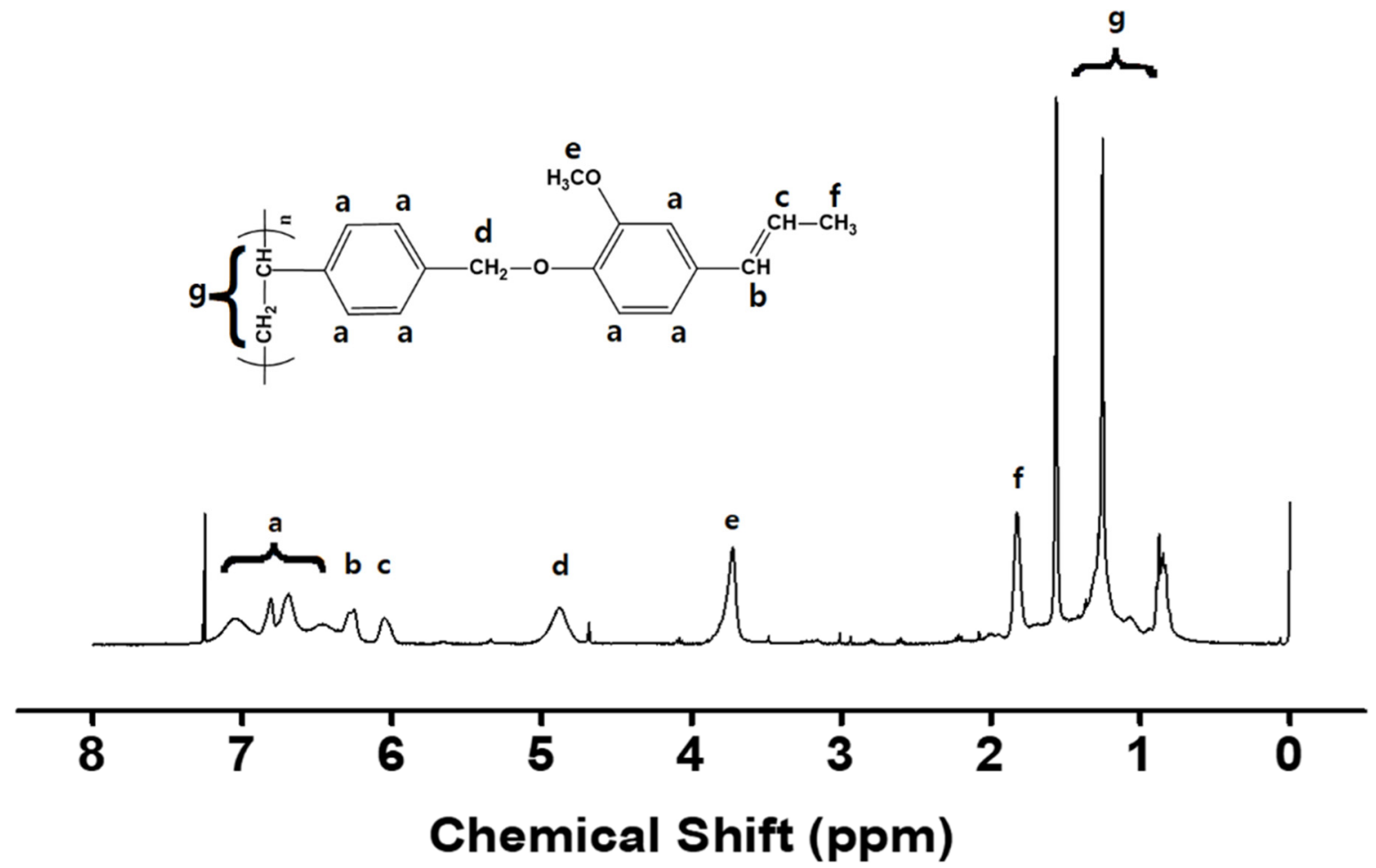

Figure 2. ${ }^{1} \mathrm{H}$ NMR (proton nuclear magnetic resonance) spectrum of PIEU100.

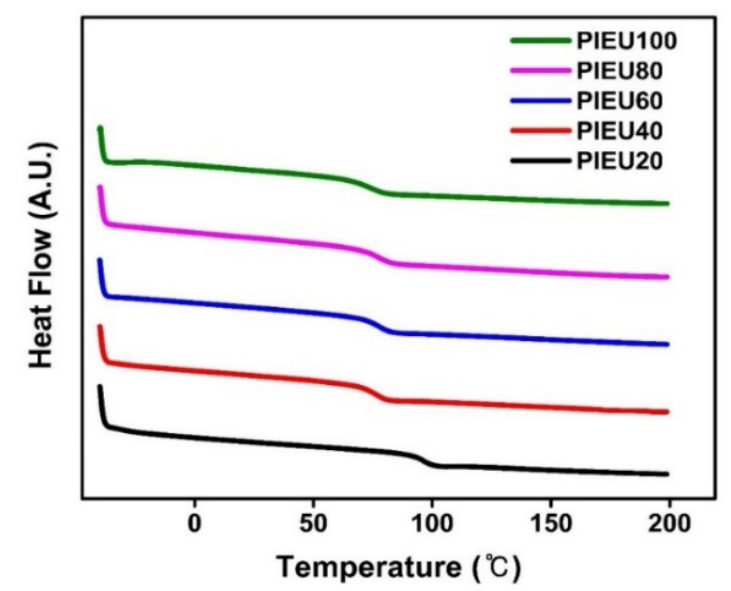

Figure 3. DSC (differential scanning calorimetry) thermogram of isoeugenol-modified polystyrene (PIEU\#).

3.2. LC Orientation Behavior of the LC Cell Fabricated with Isoeugenol-Modified Polystyrene Film

Figure 4 shows conoscopic polarized optical microscopy (POM) images of the LC cells fabricated with PIEU100 films on glass substrates at the following weight concentrations of PIEU100: 0.001, 0.01, 0.05, 0.1, and $1.0 \mathrm{wt} . \%$. At first, as shown in Figure 4a, random planar alignment was observed at a PIEU100 weight ratio of $0.001 \mathrm{wt} \%$. When PIEU100 weight ratios in solution were more than $0.01 \mathrm{wt} \%$, vertical LC aligning behavior was observed, as shown in the Maltese cross-pattern in conoscopic POM images (Figure $4 \mathrm{~b}-\mathrm{e}$ ). Therefore, a $1 \mathrm{wt}$.\% solution was selected as a coating solution to fabricate LC cells made from PIEU\# films, as previously reported by other researchers [84]. 


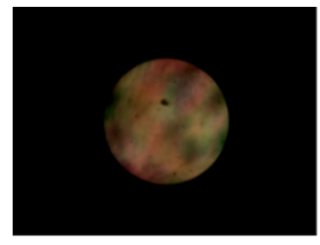

(a)

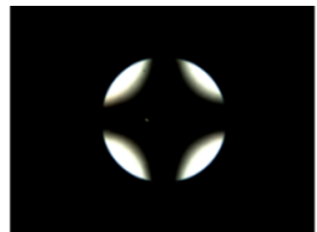

(b)

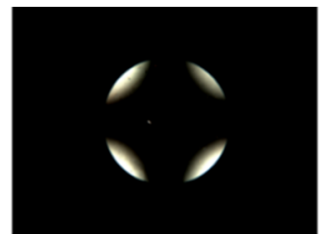

(c)

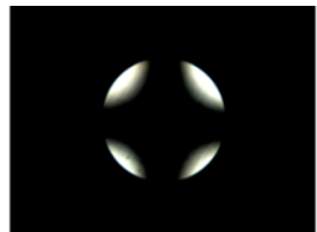

(d)

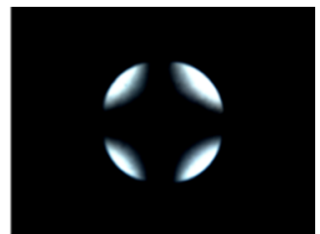

(e)

Figure 4. Conoscopic polarized optical microscopy images of the liquid crystal (LC) cells fabricated with PIEU100 films under the following weight ratios of PIEU100: (a) 0.001, (b) 0.01, (c) 0.05, (d) 0.1, and (e) $1.0 \mathrm{wt} . \%$.

Figure 5 shows photographic images of LC cells made from the PIEU\# copolymers. The LC cells fabricated with PIEU\# films with an isoeugenol side group content of less than $40 \mathrm{~mol} \%$ (PIEU40) partially showed LC texture with birefringence, while good uniformity of vertical LC alignment behavior was observed for LC cells fabricated with the polymer films with an isoeugenol side group content of at least $60 \mathrm{~mol} \%$ (PIEU60, PIEU80, and PIEU100) in the entire area image area. All of the PIEU100 films could induce stable vertical LC aligning behaviors, and the vertical LC alignment was sustained for at least several months. Therefore, as the content of the isoeugenol side groups increased, the vertical aligning capability of the LC cells made from polymers increased.

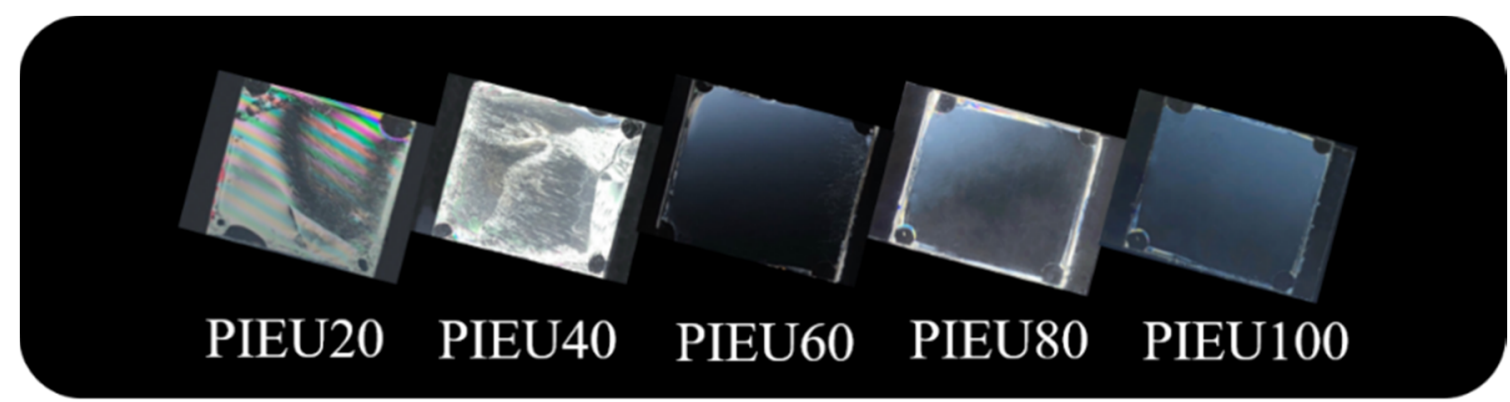

Figure 5. Photograph images of the LC cells made from PIEU\# films according to the molar content of isoeugenol moiety.

The LC aligning behaviors of the LC cells made from PIEU\# films were also examined by observing orthoscopic and conoscopic POM images, as shown in Figure 6. Random planar LC aligning behavior was observed for LC cells made with the poly(4-chloroemthylstyrene) film (figure not shown). When the content of the isoeugenol-containing monomeric part in PIEU\# was 20 and 40\%, the LC cells fabricated using the PIEU\# film exhibited random planar LC alignment behavior in the orthoscopic and conoscopic POM images. On the other hand, vertical LC aligning behavior was observed for the LC cells made with the polymeric films PIEU60, PIEU80, and PIEU100, as can be seen in the Maltese cross-pattern of the orthoscopic and conoscopic POM images.

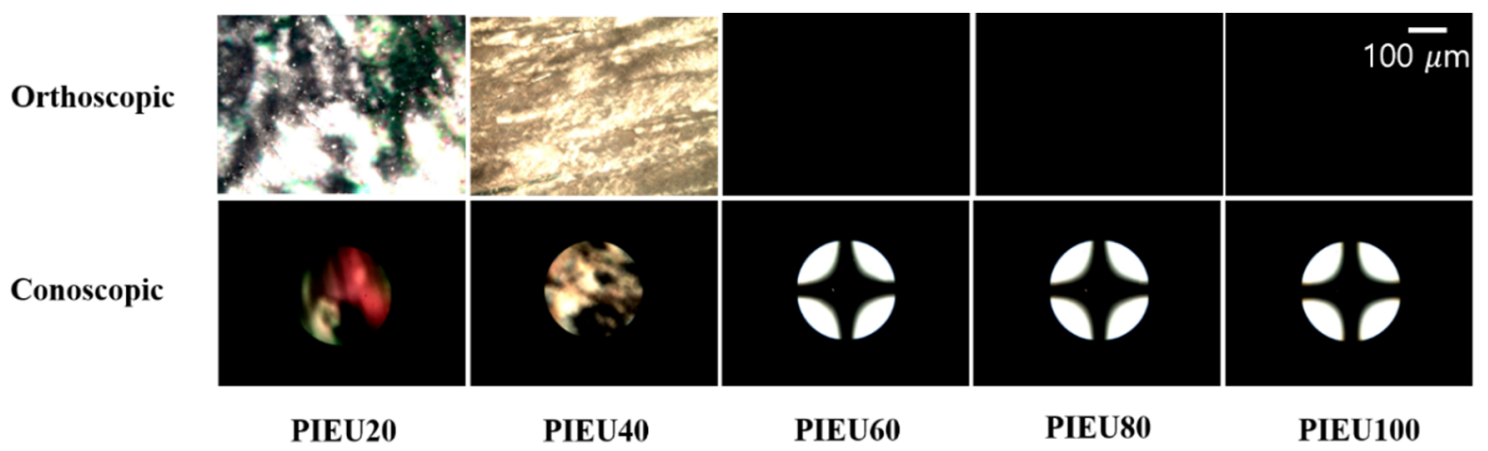

Figure 6. Orthoscopic and conoscopic polarized optical microscopy images of the LC cells made from PIEU\# (PIEU20, PIEU40, PIEU60, PIEU80, and PIEU100) films. 


\subsection{Surface Properties of Isoeugenol-Modified Polystyrene Films}

Based on the results of inducing LC alignment properties, we observed a general trend that polymers containing higher contents of the isoeugenol side group possessed a preference for vertical alignment of LC molecules. It has been known that the high tilt angles of LCs that produce vertical aligning properties are well correlated with low surface energy values on the alignment film and/or steric repulsion between LCs and the alignment surfaces $[85,86]$. For instance, polyimide derivatives having bulky and nonpolar groups such as 4-n-octyloxyphenyloxy and pentylcyclohexylbenzene exhibited vertical aligning behavior [53]. Thus, we tried to explain the aligning behavior of the LC molecules on the PIEU\# films using several surface characterization techniques, viz. surface energy value measurements. Figure 7 and Table 2 show the surface energy values of the polymer films obtained on the basis of static contact angles of water, methylene iodide, formamide, and ethylene glycol. The total surface energy was calculated using the Owens-Wendt equation, which is a summation of the polar and dispersion contributions. We also found that there is a critical surface energy value of the polymers that provides vertical LC alignment behavior. Vertical LC alignment was observed in the PIEU60, PIEU80, and PIEU100 films. The polar surface energy values of these polymers were $\leq 3.59 \mathrm{~mJ} / \mathrm{m}^{2}$ : (PIEU60-3.59 mJ $/ \mathrm{m}^{2}$, PIEU $80-2.62 \mathrm{~mJ} / \mathrm{m}^{2}$, and PIEU100-2.18 mJ $/ \mathrm{m}^{2}$ ), whereas the PIEU20 and PIEU40, which have polar surface energy values $\geq 4.81 \mathrm{~mJ} / \mathrm{m}^{2}$, did not show vertical alignment behavior. Therefore, it is appropriate to conclude that the vertical aligning capability of PIEU60, PIEU80, and PIEU100 was due to enhanced steric repulsion between LCs and polymeric surfaces caused by introducing bulky and nonpolar isoeugenol moieties into the side chain of polystyrene, and due to the low polar surface energy $\left(\leq 3.59 \mathrm{~mJ} / \mathrm{m}^{2}\right)$ originating from the peculiar molecular structure of the nonpolar carbon containing groups.

(a)

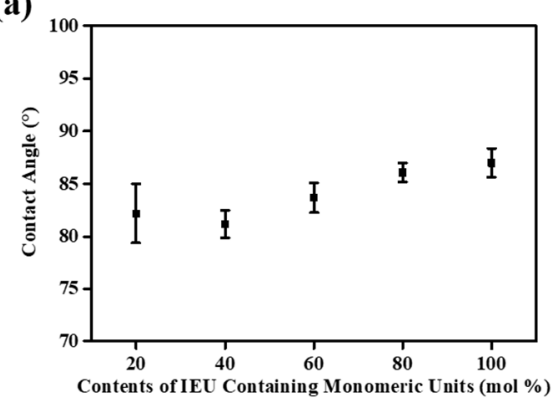

(d)

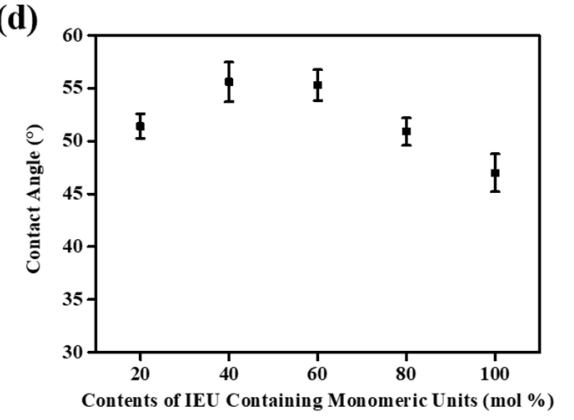

(b)

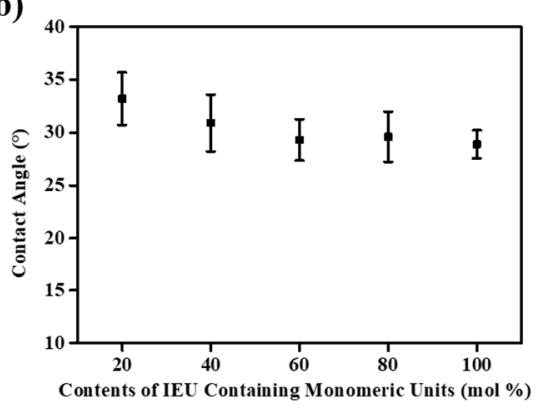

(c)

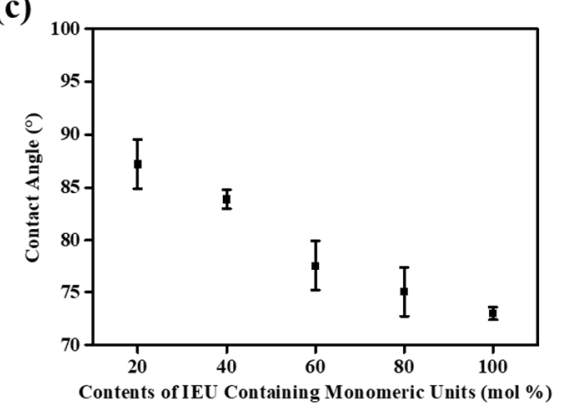

(e)

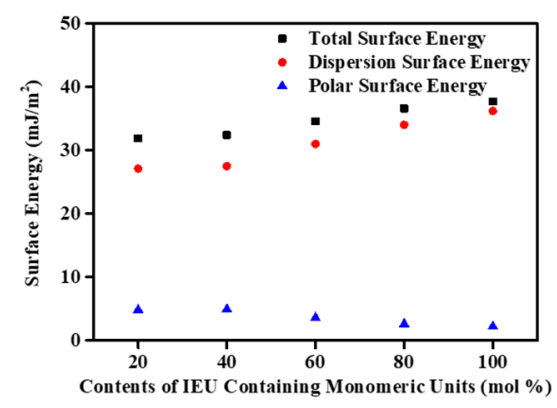

Figure 7. Contact angles of (a) water, (b) diiodomethane, (c) formamide, (d) ethylene glycol, and (e) surface energy values of PIEU\# films according to the molar content of the isoeugenol moiety in the side groups. 
Table 2. Surface energy values and liquid crystal (LC) alignment properties.

\begin{tabular}{ccccccccc}
\hline \multirow{2}{*}{$\begin{array}{c}\text { Polymer } \\
\text { Designation }\end{array}$} & Water & $\begin{array}{c}\text { Contact Angle }\left({ }^{\circ}\right)^{\mathbf{a}} \\
\text { Diiodo } \\
\text { Methane }\end{array}$ & Formamide & $\begin{array}{c}\text { Ethylene } \\
\text { Glycol }\end{array}$ & Polar & Dispersion & Surface Energy $\left(\mathbf{m J} / \mathbf{m}^{\mathbf{2}}\right)^{\mathbf{b}}$ \\
\hline PIEU20 & 82.2 & 33.2 & 87.2 & 51.4 & 4.8 & 27.1 & 31.9 & $\begin{array}{c}\text { LC Aligning } \\
\text { Ability }^{\mathbf{c}}\end{array}$ \\
PIEU40 & 81.3 & 30.9 & 83.9 & 55.6 & 4.9 & 27.5 & 32.4 & X \\
PIEU60 & 83.7 & 29.3 & 77.6 & 55.3 & 3.6 & 31.0 & 34.6 & $\mathrm{O}$ \\
PIEU80 & 86.1 & 29.6 & 75.1 & 50.9 & 2.6 & 34.0 & 36.6 & $\mathrm{O}$ \\
PIEU100 & 87.1 & 28.9 & 73.0 & 47.0 & 2.2 & 36.2 & 38.4 & $\mathrm{O}$ \\
\hline
\end{tabular}

${ }^{a}$ Measured from static contact angles. ${ }^{b}$ Calculated from Owens-Wendt's equation. ${ }^{c}$ Circle $(O)$ and cross $(X)$ indicate polymer films have vertical and random planar, tilted LC aligning ability, respectively.

\subsection{Reliability and Electro-Optical Performance of the LC Cells Fabricated with Isoeugenol-Modified Polystyrene Films}

The reliability of the LC cells made from the polymer films was investigated through a stability test of the LC alignment under harsh conditions such as high temperatures and ultraviolet (UV) energy. The thermal and UV stabilities of the LC cell made from the PIEU100 film were estimated from the POM image after heating for 1, 5, and $10 \mathrm{~min}$ at 100,150 , and $200{ }^{\circ} \mathrm{C}$, and UV irradiation at 5,10 , and $15 \mathrm{~J} / \mathrm{cm}^{2}$, respectively. As shown in Figure 8, no significant difference in the pretilt angle on the PIEU100 film with vertical LC alignment ability was observed through the Maltese cross-pattern in the conoscopic POM images, indicating that the vertical LC alignment ability of the PIEU100 LC cell was maintained even at a high temperature of $100{ }^{\circ} \mathrm{C}$ and an UV energy of $15 \mathrm{~J} / \mathrm{cm}^{2}$. The total surface energy values of the PIEU100 films obtained on the basis of the static contact angles of water, methylene iodide, formamide, and ethylene glycol were also measured after heating and UV irradiation. When the temperature was increased to $100{ }^{\circ} \mathrm{C}$ and the UV energy was increased to $15 \mathrm{~J} / \mathrm{cm}^{2}$, the polar surface energy value of the PIEU100 film was maintained in the range $2.0-2.4 \mathrm{~mJ} / \mathrm{m}^{2}$. Therefore, PIEU\# with renewable resources can be considered as a candidate LC alignment layer for eco-friendly applications.

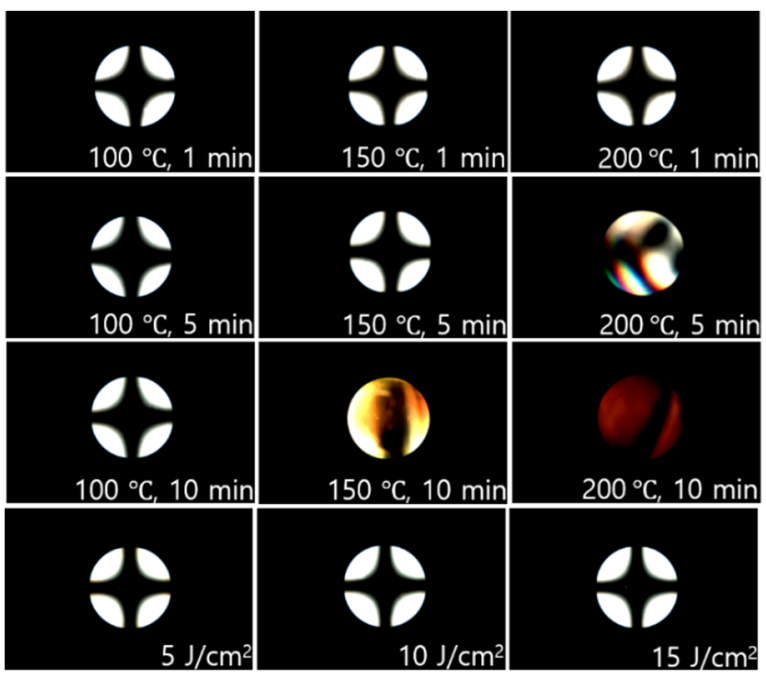

Figure 8. Concoscopic polarized optical microscopy images of the LC cells made using PIEU100 films, after thermal treatment at 100,150 , and $200{ }^{\circ} \mathrm{C}$ for 1,5 , and $10 \mathrm{~min}$, and UV treatment at 5, 10, and $15 \mathrm{~J} / \mathrm{cm}^{2}$, respectively.

\section{Conclusions}

A series of polystyrene derivatives containing plant-based isoeugenol (PIEU\#) was synthesized to investigate the liquid crystal (LC) alignment properties of these polymer films. LC cells made from films of the polymers with $\geq 60 \mathrm{~mol} \%$ of isoeugenol units (PIEU60, PIEU80, and PIEU100) showed vertical LC alignment. However, LC cells made from PIEU\# 
films with $40 \mathrm{~mol} \%$ or less of isoeugenol exhibited random planar LC alignment behavior. The vertical LC alignment was ascribed to steric repulsion between the LC molecules and the polymer surface owing to the incorporation of a nonpolar and bulky isoeugenol moiety into the side chain, and it was well correlated with polar surface energy values of the polymer $\leq 3.59 \mathrm{~mJ} / \mathrm{m}^{2}$, generated by the long alkyl groups. This provides a concept for the design of eco-friendly LC alignment layers based on renewable bioresource-containing polymer films.

Author Contributions: H.K. conceived the project. D.Y. and K.S. contributed equally that they designed and accomplished all experiments. D.Y. and K.S. synthesized and characterized the polymers. D.Y. and K.S. performed the analysis of liquid crystal orientation. D.Y. and K.S. and H.K. wrote the paper. All authors participated in discussions of the research and provided feedback for the paper. All authors have read and agreed to the published version of the manuscript.

Funding: This research was funded by Dong-A University Research Fund.

Institutional Review Board Statement: Not applicable.

Informed Consent Statement: Not applicable.

Data Availability Statement: The data presented in this study are available on request from the corresponding author.

Conflicts of Interest: The authors declare no conflict of interest.

\section{References}

1. Enfrin, M.; Dumée, L.F.; Lee, J. Nano/microplastics in water and wastewater treatment processes-origin, impact and potential solutions. Water Res. 2019, 161, 621-638. [CrossRef]

2. Our World in Data. Plastic Pollution. Available online: https:/ / ourworldindata.org/plastic-pollution (accessed on 1 September 2018).

3. Jambeck, J.R.; Geyer, R.; Wilcox, C.; Siegler, T.R.; Perryman, M.; Andrady, A.; Narayan, R.; Law, K.L. Plastic waste inputs from land into the ocean. Science 2015, 347, 768-771. [CrossRef]

4. Landon-Lane, M. Corporate social responsibility in marine plastic debris governance. Mar. Pollut. Bull. 2018, 127, 310-319. [CrossRef]

5. Kreiger, M.; Anzalone, G.C.; Mulder, M.L.; Glover, A.; Pearce, J.M. Distributed recycling of post-consumer plastic waste in rural areas. MRS Online Proc. Libr. 2012, 1492, 101-106. [CrossRef]

6. The Balance. The Decomposition of Waste in Landfills. Available online: www.thebalance.com/how-long-does-it-take-garbageto-decompose-2878033 (accessed on 22 October 2019).

7. Alabi, O.A.; Ologbonjaye, K.I.; Awosolu, O.; Alalade, O.E. Public and environmental health effects of plastic wastes disposal: A review. J. Toxicol. Risk Assess. 2019, 5, 21.

8. Shah, A.A.; Hasan, F.; Hameed, A.; Ahmed, S. Biological degradation of plastics: A comprehensive review. Biotechnol. Adv. 2008, 26, 246-265. [CrossRef] [PubMed]

9. De Sá, L.C.; Oliveira, M.; Ribeiro, F.; Rocha, T.L.; Futter, M.N. Studies of the effects of microplastics on aquatic organisms: What do we know and where should we focus our efforts in the future. Sci. Total Environ. 2018, 645, 1029-1039. [CrossRef] [PubMed]

10. Talvitie, J.; Mikola, A.; Koistinen, A.; Setälä, O. Solutions to microplastic pollution-removal of microplastics from wastewater effluent with advanced wastewater treatment technologies. Water Res. 2017, 123, 401-407. [CrossRef] [PubMed]

11. Zhang, Y.; Kang, S.; Allen, S.; Allen, D.; Gao, T.; Sillanpää, M. Atmospheric microplastics: A review on current status and perspectives. Earth-Sci. Rev. 2020, 203, 103118. [CrossRef]

12. Eriksen, M.; Thiel, M.; Prindiville, M.; Kiessling, T. Microplastic: What are the solutions. Freshw. Microplastics 2018, 58, $273-298$.

13. Coppock, R.L.; Cole, M.; Lindeque, P.K.; Queirós, A.M.; Galloway, T.S. A small-scale, portable method for extracting microplastics from marine sediments. Environ. Pollut. 2017, 230, 829-837. [CrossRef]

14. Chen, C.; Chen, L.; Li, Y.; Fu, W.; Shi, X.; Duan, J.; Zhang, W. Impacts of microplastics on organotins' photodegradation in aquatic environments. Environ. Pollut. 2020, 267, 115686. [CrossRef] [PubMed]

15. Mitrano, D.M.; Wohlleben, W. Microplastic regulation should be more precise to incentivize both innovation and environmental safety. Nat. Commun. 2020, 11, 5324. [CrossRef] [PubMed]

16. Lamberti, F.M.; Román-Ramírez, L.A.; Wood, J. Recycling of bioplastics: Routes and benefits. J. Polym. Environ. 2020, $28,1-21$. [CrossRef]

17. Song, J.H.; Murphy, R.J.; Narayan, R.; Davies, G. Biodegradable and compostable alternatives to conventional plastics. Philos. Trans. R. Soc. B Biol. Sci. 2009, 364, 2127-2139. [CrossRef]

18. Chen, X.; Yan, N. A brief overview of renewable plastics. Mater. Today Sustain. 2020, 7-8, 100031. [CrossRef] 
19. Abdul-Latif, N.; Ong, M.Y.; Nomanbhay, S.; Salman, B.; Show, P.L. Estimation of carbon dioxide $\left(\mathrm{CO}_{2}\right)$ reduction by utilization of algal biomass bioplastic in malaysia using carbon emission pinch analysis (CEPA). Bioengineered 2020, 11, 154-164. [CrossRef] [PubMed]

20. Philp, J.C.; Ritchie, R.J.; Guy, K. Biobased plastics in a bioeconomy. Trends Biotechnol. 2013, 31, 65-67. [CrossRef]

21. Hahladakis, J.N.; Velis, C.A.; Weber, R.; Iacovidou, E.; Purnell, P. An overview of chemical additives present in plastics: Migration, release, fate and environmental impact during their use, disposal and recycling. J. Hazard. Mater. 2018, 344, 179-199. [CrossRef]

22. Meeker, J.D.; Sathyanarayana, S.; Swan, S.H. Phthalates and other additives in plastics: Human exposure and associated health outcomes. Philos. Trans. R. Soc. B Biol. Sci. 2009, 364, 2097-2113. [CrossRef]

23. Talsness, C.E.; Andrade, A.J.; Kuriyama, S.N.; Taylor, J.A.; Vom Saal, F.S. Components of plastic: Experimental studies in animals and relevance for human health. Philos. Trans. R. Soc. B Biol. Sci. 2009, 364, 2079-2096. [CrossRef]

24. Perotto, G.; Ceseracciu, L.; Simonutti, R.; Paul, U.C.; Guzman-Puyol, S.; Tran, T.; Bayer, I.S.; Athanassiou, A. Bioplastics from vegetable waste via an eco-friendly water-based process. Green Chem. 2018, 20, 894-902. [CrossRef]

25. Jain, R.; Tiwari, A. Biosynthesis of planet friendly bioplastics using renewable carbon source. J. Environ. Health Sci. Eng. 2015, 13, 11. [CrossRef]

26. Haider, T.P.; Völker, C.; Kramm, J.; Landfester, K.; Wurm, F.R. Plastics of the future? The impact of biodegradable polymers on the environment and on society. Angew. Chem. Int. Ed. 2019, 58, 50-62. [CrossRef]

27. Schoukens, G.; Breen, C.; Baschetti, M.G.; Elegir, G.; Vähä-Nissi, M.; Liu, Q.; Tiekstra, S.; Simon, P. Complex packaging structures based on wood derived products: Actual and future possibilities for 1-way food packages. J. Mater. Sci. Res. 2014, 3, 58. [CrossRef]

28. Ruiz, Q.; Pourchet, S.; Placet, V.; Plasseraud, L.; Boni, G. New eco-friendly synthesized thermosets from isoeugenol-based epoxy resins. Polymers 2020, 12, 229. [CrossRef] [PubMed]

29. Koeduka, T.; Fridman, E.; Gang, D.R.; Vassao, D.G.; Jackson, B.L.; Kish, C.M.; Orlova, I.; Spassova, S.M.; Lewis, N.G.; Noel, J.P. Eugenol and isoeugenol, caracteristic aromatic constituents of spices, are biosynthesized via reduction of a coniferyl alcohol ester. Proc. Natl. Acad. Sci. USA 2006, 103, 10128-10133. [CrossRef]

30. Zhang, Y.; Xu, P.; Han, S.; Yan, H.; Ma, C. Metabolism of isoeugenol via isoeugenol-diol by a newly isolated strain of bacillus subtilis HS8. Appl. Microbiol. Biotechnol. 2006, 73, 771-779. [CrossRef] [PubMed]

31. Rastogi, S.C.; Johansen, J.D. Significant exposures to isoeugenol derivatives in perfumes. Contact Derm. 2008, 58, $278-281$. [CrossRef] [PubMed]

32. Topal, F. Anticholinergic and antidiabetic effects of isoeugenol from clove (Eugenia caryophylata) oil. Int. J. Food Prop. 2019, 22, 583-592. [CrossRef]

33. Shimoni, E.; Ravid, U.; Shoham, Y. Isolation of a Bacillus sp. capable of transforming isoeugenol to vanillin. J. Biotechnol. 2000, 78, 1-9. [CrossRef]

34. Atsumi, T.; Fujisawa, S.; Tonosaki, K. A comparative study of the antioxidant/prooxidant activities of eugenol and isoeugenol with various concentrations and oxidation conditions. Toxicol. Vitr. 2005, 19, 1025-1033. [CrossRef] [PubMed]

35. Fındık, E.; Ceylan, M.; Elmastaş, M. Isoeugenol-based novel potent antioxidants: Synthesis and reactivity. Eur. J. Med. Chem. 2011, 46, 4618-4624. [CrossRef] [PubMed]

36. Lopez, J.C.; Zon, M.A.; Fernández, H.; Granero, A.M.; Robledo, S.N. Determination of kinetic parameters of the enzymatic reaction between soybean peroxidase and natural antioxidants using chemometric tools. Food Chem. 2019, 275, 161-168. [CrossRef] [PubMed]

37. Da Silva, F.F.M.; Monte, F.J.Q.; de Lemos, T.L.G.; Do Nascimento, P.G.G.; de Medeiros Costa, A.K.; De Paiva, L.M.M. Eugenol derivatives: Synthesis, characterization, and evaluation of antibacterial and antioxidant activities. Chem. Cent. J. 2018, 12, 34. [CrossRef] [PubMed]

38. Bortolomeazzi, R.; Verardo, G.; Liessi, A.; Callea, A. Formation of dehydrodiisoeugenol and dehydrodieugenol from the reaction of isoeugenol and eugenol with DPPH radical and their role in the radical scavenging activity. Food Chem. 2010, 118, 256-265. [CrossRef]

39. Mutlu-Ingok, A.; Devecioglu, D.; Dikmetas, D.N.; Karbancioglu-Guler, F.; Capanoglu, E. Antibacterial, antifungal, antimycotoxigenic, and antioxidant activities of essential oils: An updated review. Molecules 2020, 25, 4711. [CrossRef]

40. Gülçin, İ. Antioxidant activity of eugenol: A structure-activity relationship study. J. Med. Food 2011, 14, 975-985. [CrossRef]

41. Lobo, V.; Patil, A.; Phatak, A.; Chandra, N. Free radicals, antioxidants and functional foods: Impact on human health. Pharmacogn. Rev. 2010, 4, 118. [CrossRef]

42. Biswas, S.; Das, R.; Banerjee, E.R. Role of free radicals in human inflammatory diseases. AIMS Biophys. 2017, 4, 596-614. [CrossRef]

43. Sainz, R.M.; Lombo, F.; Mayo, J.C. Radical decisions in cancer: Redox control of cell growth and death. Cancers $2012,4,442-474$. [CrossRef]

44. Liu, Z. Chemical methods to evaluate antioxidant ability. Chem. Rev. 2010, 110, 5675-5691. [CrossRef]

45. Chen, J.; Yang, J.; Ma, L.; Li, J.; Shahzad, N.; Kim, C.K. Structure-antioxidant activity relationship of methoxy, phenolic hydroxyl, and carboxylic acid groups of phenolic acids. Sci. Rep. 2020, 10, 2611. [CrossRef] [PubMed]

46. Zuo, A.; Dong, H.; Yu, Y.; Shu, Q.; Zheng, L.; Yu, X.; Cao, S. The antityrosinase and antioxidant activities of flavonoids dominated by the number and location of phenolic hydroxyl groups. Chin. Med. 2018, 13, 51. [CrossRef] [PubMed]

47. Sohilait, H.J.; Kainama, H. Free radical scavenging activity of essential oil of eugenia caryophylata from amboina island and derivatives of eugenol. Open Chem. 2019, 17, 422-428. [CrossRef] 
48. Al-Amiery, A.A.; Kadhum, A.A.H.; Obayes, H.R.; Mohamad, A.B. Synthesis and antioxidant activities of novel 5-chlorocurcumin, complemented by semiempirical calculations. Bioinorg. Chem. Appl. 2013, 2013, 354982. [CrossRef] [PubMed]

49. Aadesariya, M.K.; Ram, V.R.; Dave, P.N. Evaluation of antioxidant activities by use of various extracts from abutilon pannosum and grewia tenax leaves in the kachchh region. MOJ Food Process. Technol. 2017, 17, 359.

50. Nielsen, C.K.; Kjems, J.; Mygind, T.; Snabe, T.; Schwarz, K.; Serfert, Y.; Meyer, R.L. Enhancing the antibacterial efficacy of isoeugenol by emulsion encapsulation. Int. J. Food Microbiol. 2016, 229, 7-14. [CrossRef]

51. Sánchez-González, L.; Vargas, M.; González-Martínez, C.; Chiralt, A.; Chafer, M. Use of essential oils in bioactive edible coatings: A review. Food Eng. Rev. 2011, 3, 1-16. [CrossRef]

52. Nielsen, C.K.; Subbiahdoss, G.; Zeng, G.; Salmi, Z.; Kjems, J.; Mygind, T.; Snabe, T.; Meyer, R.L. Antibacterial isoeugenol coating on stainless steel and polyethylene surfaces prevents biofilm growth. J. Appl. Microbiol. 2018, 124, 179-187. [CrossRef]

53. Kather, M.; Skischus, M.; Kandt, P.; Pich, A.; Conrads, G.; Neuss, S. Functional isoeugenol-modified nanogel coatings for the design of biointerfaces. Angew. Chem. Int. 2017, 56, 2497-2502. [CrossRef] [PubMed]

54. Wang, R.; Hu, X.; Pan, J.; Zhang, G.; Gong, D. Interaction of isoeugenol with calf thymus DNA and its protective effect on DNA oxidative damage. J. Mol. Liq. 2019, 282, 356-365. [CrossRef]

55. Medeiros, D.; Oliveira-Júnior, J.; Nóbrega, J.; Cordeiro, L.; Jardim, J.; Souza, H.; Silva, G.; Athayde-Filho, P.; Barbosa-Filho, J.; Scotti, L. Isoeugenol and hybrid acetamides against candida albicans isolated from the oral cavity. Pharmaceuticals 2020, 13, 291. [CrossRef]

56. Ju, C.; Kim, T.; Kang, H. Renewable, eugenol-modified polystyrene layer for liquid crystal orientation. Polymers 2018, 10, 201. [CrossRef] [PubMed]

57. Ju, C.; Kim, T.; Kang, H. Liquid crystal alignment behaviors on capsaicin substituted polystyrene films. RSC Adv. 2017, 7, 41376-41383. [CrossRef]

58. Ju, C.; Kang, S.; Kim, T.; Park, C.; Kang, H. Vertical liquid crystal alignment of comb-like alkyl hydroxybenzoate-substituted polystyrene. Crystals 2019, 9, 281. [CrossRef]

59. Shen, Y.; Dierking, I. Perspectives in liquid-crystal-aided nanotechnology and nanoscience. Appl. Sci. 2019, 9, 2512. [CrossRef]

60. Williams, C.K.; Hillmyer, M.A. Polymers from renewable resources: A perspective for a special issue of polymer reviews. Polym. Rev. 2008, 48, 1-10. [CrossRef]

61. Kato, T.; Gupta, M.; Yamaguchi, D.; Gan, K.P.; Nakayama, M. Supramolecular association and nanostructure formation of liquid crystals and polymers for new functional materials. Bull. Chem. Soc. Jpn. 2021, 94, 357-376. [CrossRef]

62. Manda, R.; Pagidi, S.; Heo, Y.; Lim, Y.J.; Kim, M.; Lee, S.H. Electrically tunable photonic band gap structure in monodomain blue-phase liquid crystals. NPG Asia Mater. 2020, 12, 42. [CrossRef]

63. Xia, C.; Zhou, D.; Su, Y.; Zhou, G.; Yao, L.; Sun, W.; Liu, Y. A liquid-crystal-based immunosensor for the detection of cardiac troponin I. Analyst 2020, 145, 4569-4575. [CrossRef]

64. Yan, Z.; Yao, J.; Hou, Y.; Zhou, J.; Sun, J.; Huang, X. Polarized optical properties in liquid crystals devices with photoaligned metal nanoparticle gratings. Appl. Phys. A 2021, 127, 1-7. [CrossRef]

65. Ju, C.; Park, C.; Kim, T.; Kang, H. Vertical alignment of liquid crystals on plant-based vanillin derivative-substituted polystyrene films. RSC Adv. 2019, 9, 14188-14193. [CrossRef]

66. Yoon, W.; Lee, K.M.; Evans, D.R.; McConney, M.E.; Kim, D.; Jeong, K. Giant surfactants for the construction of automatic liquid crystal alignment layers. J. Mater. Chem. C 2019, 7, 8500-8514. [CrossRef]

67. Lee, S.W.; Kim, S.I.; Park, Y.H.; Reea, M.; Rim, Y.N.; Yoon, H.J.; Kim, H.C.; Kim, Y.B. Liquid-crystal alignment on the rubbed film surface of semi-flexible copolyimides containing n-alkyl side groups. Mol. Cryst. Lip. Cryst. 2000, 349, 279-282. [CrossRef]

68. Kim, T.; Ju, C.; Kang, H. Vertical alignment of liquid crystal on tocopherol-substituted polystyrene films. Liq. Cryst. 2018, 45, 801-810. [CrossRef]

69. Tsuda, Y.; Matsuda, Y.; Matsuda, T. Soluble polyimides bearing long-chain alkyl groups on their side chain via polymer reaction. Int. J. Polym. Sci. 2012, 2012, 972541. [CrossRef]

70. Abdollahi, A.; Roghani-Mamaqani, H.; Salami-Kalajahi, M. Morphology evolution of functionalized styrene and methyl methacrylate copolymer latex nanoparticles by one-step emulsifier-free emulsion polymerization. Eur. Polym. J. 2020, 133, 109790. [CrossRef]

71. Niknejad, A.S.; Bazgir, S.; Sadeghzadeh, A.; Shirazi, M.M.A. Styrene-acrylonitrile (SAN) nanofibrous membranes with unique properties for desalination by direct contact membrane distillation (DCMD) process. Desalination 2020, 488, 114502. [CrossRef]

72. Dögüüsü, D.K.; Damlıŏlu, Y.; Alkan, C. Poly (Styrene-Co-Divinylbenzene-Co-Acrylamide)/N-octadecane microencapsulated phase change materials for thermal energy storage. Sol. Energy Mater. Sol. Cells 2019, 198, 5-10. [CrossRef]

73. Straus, S.; Madorsky, S.L. Thermal stability of polydivinylbenzene and of copolymers of styrene with divinylbenzene and with trivinylbenzene. J. Res. Natl. Bur. Stand. A Phys. Chem. 1961, 65, 243. [CrossRef] [PubMed]

74. Kang, H.; Kwon, K.; Kang, D.; Lee, J. Enhanced, perpendicular liquid-crystal alignment on rubbed films of a coumarin-containing polystyrene. Macromol. Chem. Phys. 2007, 208, 1853-1861. [CrossRef]

75. Kim, T.; Ju, C.; Kang, H. Vertical liquid crystal orientation of phytochemical-based oryzanol modified polystyrene. RSC Adv. 2018, 8, 1569-1575. [CrossRef]

76. Kim, T.; Ju, C.; Park, C.; Kang, H. Enhanced, parallel liquid crystal alignment based on polystyrene substituted with phthalimidoyl groups. RSC Adv. 2019, 9, 9755-9761. [CrossRef] 
77. Kang, H.; Lee, J.; Nam, B.; Bae, J.W. Liquid crystal alignment behavior on transparent cellulose films. RSC Adv. 2015, 5, 38654-38659. [CrossRef]

78. Li, X.; Yanagimachi, T.; Bishop, C.; Smith, C.; Dolejsi, M.; Xie, H.; Kurihara, K.; Nealey, P.F. Engineering the anchoring behavior of nematic liquid crystals on a solid surface by varying the density of liquid crystalline polymer brushes. Soft Matter 2018, 14, 7569-7577. [CrossRef]

79. Cai, F.; Zheng, F.; Lu, X.; Lu, Q. Control of the alignment of liquid crystal molecules on a sequence-polymerized film by surface migration and polarized light irradiation. Polym. Chem. 2017, 8, 7316-7324. [CrossRef]

80. Costa, E.; Aquilano, D. Experimental value of the specific surface energy of the cleavage $\{10.4\}$ calcite rhombohedron in the presence of its saturated aqueous solution. Crystals 2018, 8, 238. [CrossRef]

81. Bandzierz, K.; Reuvekamp, L.; Dryzek, J.; Dierkes, W.; Blume, A.; Bielinski, D. Influence of network structure on glass transition temperature of elastomers. Materials 2016, 9, 607. [CrossRef]

82. White, R.P.; Lipson, J.E. Polymer free volume and its connection to the glass transition. Macromolecules 2016, $49,3987-4007$. [CrossRef]

83. Gedde, U. Polymer Physics; Springer: Dordrecht, The Netherlands, 1995; pp. 79-82.

84. Kang, H.; Seo, J.G.; Kang, D.; Lee, J. Liquid crystal alignment properties of poly (styrenesulphonate)/alkyltrimethylammonium complexes. Liq. Cryst. 2013, 40, 492-498. [CrossRef]

85. Kang, H.; Park, J.S.; Sohn, E.; Kang, D.; Rosenblatt, C.; Lee, J. Polyimide blend alignment layers for control of liquid crystal pretilt angle through baking. Polymer 2009, 50, 5220-5227. [CrossRef]

86. Liu, B.; Meng, C.; Chen, L. Role of monomer alkyl chain length in pretilt angle control of polymer-stabilized liquid crystal alignment system. J. Phys. Chem. C 2017, 121, 21037-21044. [CrossRef] 